\title{
Scarping predictability of sandy beaches in a multidirectional wave basin
}

\author{
Predictibilidad de la formación de escarpe en playas de arena \\ en un tanque multidireccional de oleaje
}

\author{
A Payo ${ }^{1 *}, \mathrm{~N}$ Kobayashi², J Muñoz-Pérez ${ }^{3}$, F Yamada ${ }^{1}$ \\ ${ }^{1}$ Graduate School of Science and Technology, University of Kumamoto, 2-39-1, Kurokami, Kumamoto, 860-8555, Japan. \\ *E-mail: andres@kumamoto-u.ac.jp \\ ${ }^{2}$ Center for Applied Coastal Research, University of Delaware, Newark, DE 19716, USA. \\ ${ }^{3}$ Applied Physics Department, CASEM, University of Cádiz, Puerto Real, 11510, Spain.
}

\begin{abstract}
Our ability to predict beach erosion above the still water level (SWL) is still not satisfactory due to the lack of adequate technology to accurately measure the sediment concentration and velocity in very shallow water, including the swash zone where the beach face is intermittently covered with water and exposed to the atmosphere. A simple procedure is proposed here to improve our predictive capability for the particular case of scarping erosion caused by wind-generated waves above the SWL. If the slope at the steep scarp is larger than the limiting slope of the internal sediment friction, the steep face is assumed to be eroded due to the computed offshore sediment transport at the toe of the scarp. The bedload and suspended sediment transport at the toe of the scarp was computed using a time-averaged model that includes the steep bottom slope effect. The model was validated against a novel experiment in a multidirectional wave basin, where scarping was reproduced. The water level was raised in four steps to reproduce the shoreface erosion, berm overwash and berm erosion, successively. Horizontal and tilted berms were tested against similar normal incident irregular waves to compare the performance of the profile without and with ponding, respectively. For the tilted case, ponding appeared when the tilted berm was overtopped. No ponding was observed for the horizontal berm test even when the berm was overtopped. The predictability was estimated using the Brier skill score (BSS). The predictability of the scarping was good (BSS $\geq 0.6$ ) for the horizontal berm test and fair (BSS $\geq 0.4$ ) for the tilted berm test. This decrease in the predictability may be related to the ponding, which is not included in the model.
\end{abstract}

Key words: bedload, bottom slope effect, beach profile model, erosion.

\section{Resumen}

Nuestra capacidad de predecir la erosión de la playa por encima del nivel medio del mar en reposo se encuentra todavía en desarrollo. Esto es principalmente debido a la falta de tecnología que permita medir con la precisión necesaria la concentración de sedimentos y la velocidad del flujo en aguas poco profundas, incluyendo la zona de swash que es intermitentemente sumergida y expuesta a la atmósfera. En un intento de mejorar nuestra capacidad de predicción, se propone un modelo sencillo para el caso particular de la formación de escarpe por encima del nivel medio del mar en reposo debido al ataque del oleaje generado por el viento. Si la pendiente del escarpe es superior a la pendiente de equilibrio del sedimento, la tasa de erosión del frente de arena se supone igual a la erosión estimada al pie del escarpe. El transporte de fondo y en suspensión al pie del escarpe es calculado empleando un modelo promediado en el tiempo al que se ha incluido el efecto de la pendiente del fondo sobre el transporte. El modelo es validado con un experimento en un tanque multidireccional de oleaje, donde se reprodujo la formación del escarpe. El nivel del agua en el tanque se elevó en cuatro pasos para reproducir la erosión del frente de playa, el rebosamiento y la erosión de la berma sucesivamente. Las bermas horizontal e inclinada hacia tierra se sometieron a oleajes irregulares similares de incidencia normal para examinar la influencia de la acumulación de agua tras la berma sobre la evolución del perfil de playa. En el caso de la berma inclinada se observó una acumulación esporádica de agua tras la cresta de la berma cuando ésta era rebasada. No se observó acumulación de agua tras la berma horizontal. La capacidad predictiva del modelo fue estimada en base a la escala de Brier (BSS por sus siglas en inglés), resultando buena (BSS $\geq 0.6$ ) para el caso de la berma horizontal y justa (BSS $\geq 0.4$ ) para el caso de la berma inclinada. Esta disminución en la predictibilidad puede estar relacionada con el rebosamiento sobre la berma, el cual no ha sido considerado en el modelo.

Palabras clave: transporte de fondo, efecto de la pendiente del fondo, erosión del perfil de playa.

\section{Introduction}

In Europe, an estimated average of 5400 million euros are used per year to mitigate coastal erosion and protect dwellings, resorts, infrastructure and other real estate along the coastline

\section{Introducción}

Se estima que en Europa se invierten un promedio de 5400 millones de euros anuales para paliar los efectos de la erosión costera y proteger zonas residenciales, complejos turísticos, 
(www.eurosion.org). The processes involved in coastal changes are complex but most scientists agree that rising sea level, coupled with the depletion of sediment sources, will result in severe beach erosion and shoreline retreat. In order to quantify the rate of retreat under different possible scenarios, robust predictive models are needed. A model is regarded robust when no fine tuning of the model's empirical parameter is needed to reproduce the observed bathymetric changes. The quantitative understanding and modelling abilities of sediment transport has improved significantly in the last decade. Van Rijn et al. (2003) showed that calibrated profile models could simulate the behaviour of the outer and inner bars on the storm scale, but the profile change above the still water level (hereinafter SWL) is still an elusive problem. The main reason is the lack of adequate technology to accurately measure the sediment concentration and velocity in very shallow water, including the swash zone where the beach face is intermittently covered with water and exposed to the atmosphere (e.g., White 1998, van Rijn et al. 2007).

In this paper, the erosion mechanism of scarping above the SWL is evaluated. Scarping is the erosion of the beach face with a very steep-fronted slope. Figure 1 shows a typical beach profile above the SWL where scarping has occurred. In this figure the beach has a gentle slope until the toe of the scarp where the slope is almost vertical. Seymour et al. (2005) observed rapid erosion of a flat-topped berm fill and have suggested that if the slumping of the steep-fronted scarp is not considered, the erosion is severely underpredicted. They also observed that scarping resulted in alongshore quasiperiodic variability but the causes for the formation of such nonuniformity are unknown. In this study, we address the problem of predicting the erosion rate above the SWL on an alongshore uniform beach consisting of well-sorted sand under the attack of irregular normally incident short waves. Slumping of the scarp and the bottom slope effect are included in the model proposed by Schmied et al. (2006). If the bottom slope and slumping effects are not included, this numerical model has been found to underpredict the erosion of a steep berm on a sandy beach (Payo et al. 2006). The performance of the improved model is evaluated quantitatively using the Brier

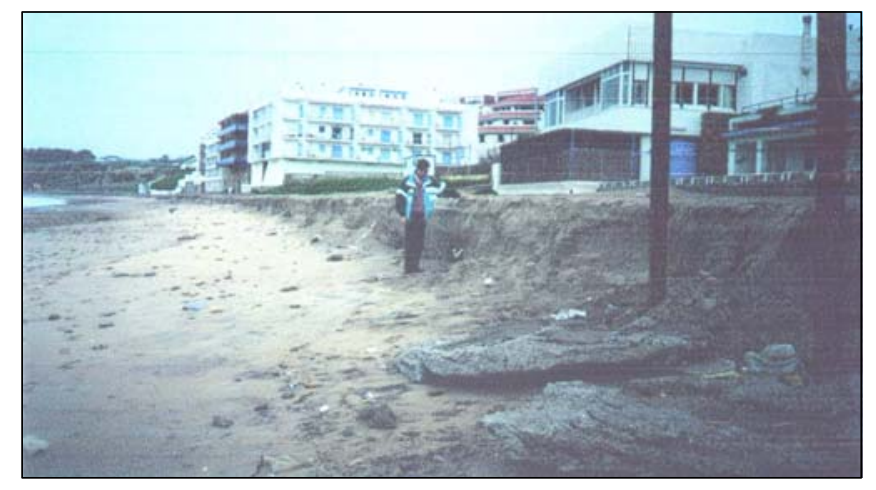

Figure 1. Scarping at Fuentebravía Beach, Cádiz, SW Spain.

Figura 1. Escalón en la playa de Fuentebravía, Cádiz, SO de España. infraestructuras y otros bienes raíces a lo largo de la costa (www.eurosion.org). Los procesos relacionados con la erosión costera son complejos, sin embargo, la mayoría de los científicos están de acuerdo en que la elevación del nivel del mar junto con la disminución de las fuentes de sedimentos aumentarán la erosión de la costa y el retroceso de la línea de playa. Para cuantificar esta tasa de retroceso ante los posibles futuros escenarios, es necesario el uso de modelos predictivos robustos. Se considera robusto aquel modelo cuyos parámetros empíricos no necesitan ser calibrados para reproducir los cambios batimétricos observados. Nuestro conocimiento y capacidad predictiva del transporte de sedimentos han mejorado significativamente en la ultima década. Van Rijn et al. (2003) mostraron cómo algunos modelos de variación del perfil de playa, después de ser calibrados, podían reproducir los movimientos de la barra de arena en la escala de tormentas, no obstante la predicción de las variaciones del perfil por encima del nivel medio del mar en reposo (en adelante referido por sus siglas en inglés, SWL) todavía se encuentra en una etapa temprana de desarrollo. La principal razón de ello es la falta de tecnología para medir, con la precisión adecuada, la concentración de sedimento y la velocidad del flujo en aguas poco profundas, incluyendo la zona de swash donde el frente de playa es intermitentemente sumergido y expuesto a la atmósfera (e.g., White 1998, van Rijn et al. 2007).

En este trabajo se analizan los mecanismos de erosión por escarpe por encima del SWL. La erosión por escarpe es la erosión del frente de playa debida a la formación de pendientes muy elevadas. La figura 1 muestra un perfil de playa típico por encima del SWL erosionado por escarpe. Se observa cómo la playa tiene una pendiente suave hasta el pie del escarpe (escalón) donde la pendiente es casi vertical. Seymour et al. (2005) observaron la rápida erosión de una regeneración de playa, con berma horizontal, sugiriendo que si la erosión por avalancha del escarpe no es tenida en cuenta, la tasa de erosión es severamente subestimada. También observaron cómo la erosión por escarpe presentaba una variabilidad longitudinal cuasiperiódica, pero aún no se conocen las razones que dan lugar a esta falta de uniformidad. En este estudio se aborda el problema de la estimación de la tasa de erosión por encima del SWL en una playa inicialmente uniforme, de arena bien seleccionada, bajo la acción de oleaje irregular de periodo y de incidencia predominantemente normal a la playa. Se mejoró el modelo de Schimed et al. (2006) al incluirle la erosión por avalancha del escarpe y el efecto de la pendiente del fondo sobre el transporte de sedimentos. Si no se incluyen estos efectos se ha comprobado que este modelo numérico subestima la erosión de una berma de pendiente elevada en una playa de arena (Payo et al. 2006). La capacidad predictiva de los cambios morfológicos del modelo mejorado ha sido evaluada cuantitativamente mediante la escala de Brier (BSS por sus siglas en inglés). Esta escala se seleccionó para permitir la comparación con otros modelos de perfiles de playa evaluados recientemente (e.g., van Rijn et al. 2003). El modelo mejorado, empleando los valores por defecto de sus parámetros empíricos, obtiene la calificación de bueno a aceptable por encima del SWL. 


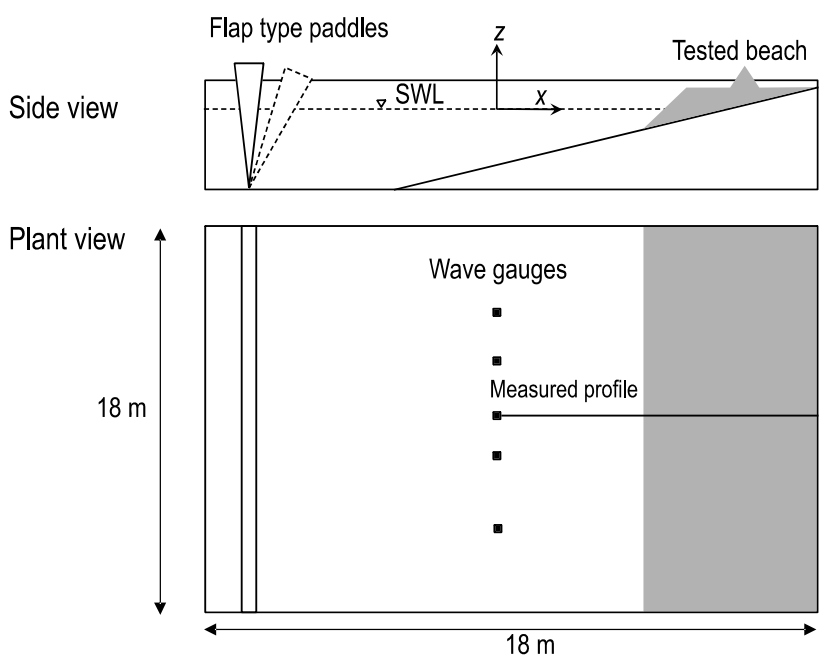

Figure 2. Experiment layout at the Ocean Engineering Laboratory, University of Delaware.

Figura 2. Diseño del experimento en el Laboratorio de Ingeniería Oceánica, Universidad de Delaware.

skill score. This score is selected for comparison with other recent evaluations of profile models (e.g., van Rijn et al. 2003). The improved model using standard values of its empirical parameters has produced a good to fair performance of the model above the SWL.

This paper is organized as follows. Section 2 summarizes the berm erosion experiment and shows the measured profile evolution. Section 3 presents the extension of the timeaveraged model of Schmied et al. (2006) to include the bottom slope and scarping effects. Section 4 shows the computed versus measured profiles. Section 5 presents the cross-shore variation of the estimated predictability. Section 6 summarizes the findings of this study.

\section{Berm erosion experiments}

Two tests were conducted at the University of Delaware in a wave basin that was $18 \mathrm{~m}$ long, $18 \mathrm{~m}$ wide and $1 \mathrm{~m}$ deep, with a concrete slope of 0.05 . Seven tons of well-sorted siliceous sand with median diameter $D_{50}=0.19 \mathrm{~mm}$ were used to build a beach on the concrete slope. Normally incident directional random waves were generated by 34 flap-type paddles based on a shallow water modification of the JONSWAP spectrum with its peak enhancement factor of 3.3 (Bouws et al. 1985). The directional spreading of typical sea waves was employed in the wave generation software. The directional spreading at the breaking zone was estimated to be approximately $\pm 5^{\circ}$ relative to the shore normal. Five capacitance wave gauges were used to measure the temporal variations of the free surface elevation along the beach. The experimental layout is shown in figure 2. Two different profiles were built: flat (horizontal) berm and tilted (0.03 landward slope) berm. These two profiles were characterized by a 0.6 -m-wide berm and a steep foreshore slope of 0.2 . The water level was increased in
A continuación se presenta la organización de este documento. En la sección 2 se resumen los experimentos de erosión de la berma y se muestra la evolución de los perfiles de playa. En la sección 3 se presenta la extensión del modelo promediado en el tiempo de Schmied et al. (2006), en la que se incluyen el efecto de la pendiente del fondo y la erosión del escarpe. En la sección 4 se comparan los perfiles medidos con los observados. La sección 5 muestra la variabilidad transversal de la predictibilidad del modelo. Finalmente se resumen las aportaciones de este trabajo.

\section{Experimentos de erosión de la berma}

Se realizaron dos ensayos en el tanque multidireccional de oleaje en la Universidad de Delaware de $18 \mathrm{~m}$ de lado y $1 \mathrm{~m}$ de profundidad, con una pendiente de cemento de 0.05. Se emplearon $7 \mathrm{t}$ de arena silícea bien seleccionada de diámetro medio $D_{50}=0.19 \mathrm{~mm}$ para la construcción de la dirección irregular de incidencia predominantemente normal mediante el uso de 34 palas tipo bandera basado en el espectro de energía JONSWAP modificado para aguas someras, con parámetro de dispersión direccional de 3.3 (Bouws et al. 1985). Esta dispersión direccional, típica de oleaje no organizado, se empleó en el software de generación de oleaje. La dispersión direccional en la zona de rompiente fue estimada en aproximadamente $\pm 5^{\circ}$ respecto a la normal a la playa. Se emplearon cinco galgas de capacidad para medir la variación temporal de la superficie libre a lo largo de la playa. La figura 2 muestra el esquema del diseño experimental. Se ensayaron dos tipos de perfiles: berma plana (horizontal) y berma inclinada (hacia el lado de tierra con pendiente 0.03). Estos dos perfiles se caracterizaban por una berma de $0.6 \mathrm{~m}$ de ancho y un frente de playa de elevada pendiente (0.2). El nivel de agua en el tanque fue elevado en cuatro pasos para simular la erosión del frente de playa (I), rebosamiento sobre la berma (II), erosión de la berma (III), y destrucción de la berma (IV), sucesivamente. El ensayo se dio por terminado cuando la erosión alcanzó el final de la berma. La duración, nivel medio del agua en reposo, altura de ola significante espectral y periodo de pico, medidos en las galgas de oleaje usadas como condición de contorno del modelo, se muestran en la tabla 1.

El perfil de playa se construyó por segmentos de $1.5 \mathrm{~m}$ de ancho aproximadamente, con la ayuda de dos perfiles de referencia. La arena era depositada uniformemente entre los dos perfiles y compactada manualmente. Al finalizar la construcción de la playa, el nivel del agua se elevó hasta que la berma quedó completamente sumergida para humedecer la arena. El nivel del agua se redujo hasta el nivel correspondiente del primer paso, y se inició la secuencia de experimentos. Al final de cada paso, se midió el perfil de la playa cada $5 \mathrm{~cm}$ con un perfilador mecánico en un transecto localizado en el centro del tanque. El mismo perfil fue medido en tres ocasiones para 
Table 1. Duration, depth, wave height and period at wave gauges for each test.

Tabla 1. Duración, profundidad, altura de ola y periodo en las galgas de oleaje para cada ensayo.

\begin{tabular}{|c|c|c|c|c|c|c|c|}
\hline \multirow{2}{*}{ Step } & \multirow{2}{*}{$\begin{array}{l}\text { Duration } \\
\text { (min) }\end{array}$} & \multicolumn{3}{|c|}{ Flat berm } & \multicolumn{3}{|c|}{ Tilted berm } \\
\hline & & Depth (cm) & $H_{m 0}(\mathrm{~cm})$ & $T_{p}(\mathrm{~s})$ & Depth (cm) & $H_{m 0}(\mathrm{~cm})$ & $T_{p}(\mathrm{~s})$ \\
\hline I & 143 & 22.0 & 6.50 & 1.07 & 22.0 & 6.35 & 1.10 \\
\hline II & 15 & 25.3 & 7.01 & 1.07 & 26.0 & 7.07 & 1.12 \\
\hline III & 30 & 27.4 & 7.43 & 1.09 & 27.5 & 7.40 & 1.12 \\
\hline IV & 25 & 29.8 & 7.95 & 1.09 & 30.4 & 7.89 & 1.11 \\
\hline
\end{tabular}

four steps to simulate foreshore erosion (I), berm overwash (II), berm erosion (III), and berm destruction (IV), successively. The test was terminated when the erosion reached the landward end of the berm. The duration, still water depth, spectral significant wave height, and spectral peak period at the wave gages, used as boundary conditions for the model, are listed in table 1 .

The beach profile was built in segments of about $1.5 \mathrm{~m}$ width with the help of two wood frames. The sand was dumped between the two wood frames, distributed and compacted evenly by hand. After the beach was built, the water level was increased until the entire berm was completely submerged to wet the sand. The water level was decreased to the SWL for the first step, and the four-step sequence was initiated. At the end of each step, one profile was measured every $5 \mathrm{~cm}$ using a mechanical profiler in the middle of the tank. The same profile was measured three times to check the accuracy of the measurements. The maximum difference between the measured profiles was $1 \mathrm{~cm}$ at the toe of the foreshore. The accuracy was $\pm 0.5 \mathrm{~cm}$ in the shallower region and on the berm.
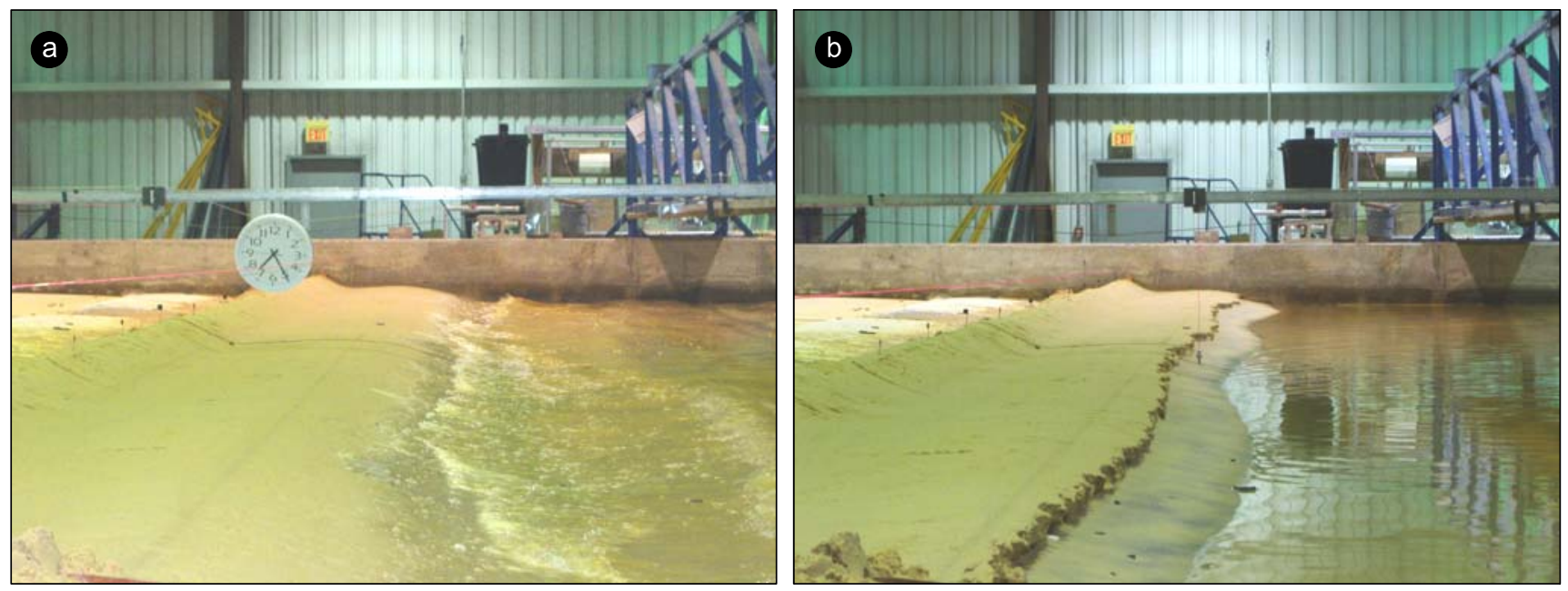

Figure 3. Scarping simulation in a multidirectional wave basin: (a) beach shape at the beginning of the horizontal berm test and (b) scarped berm after 143 min of wave action.

Figura 3. Reproducción de erosión por escarpe en tanque multidreccional de oleaje. (a) Forma de la playa al inicio del ensayo de berma horizontal y (b) berma erosionada por escarpe tras 143 min sometida a acción del oleaje. 
Scarping was initiated after a few minutes of wave action during step I and clearly visible at the end of this step (see fig. 3a, b). The scarp was washed away during step II, when the water level was raised. The main qualitative difference between the horizontal and tilted berm tests was the ponding during step III on the tilted berm. The profile evolutions are shown in figures 3 and 4 . Although the initial beach was rectilinear and the predominant incident wave angle was normal, the measured profiles showed that the sand volume was not conserved in this particular section of the beach. This may have occurred because the concrete slope was not completely uniform alongshore, as indicated by Payo et al. (2006). Therefore, the sediment transport was not limited to the cross-shore. The ratio between the eroded sand volume and the accreted sand volume varied for each step, the average being 0.3 .

\section{Extension to steep bottoms and scarping}

The formulation of bedload and suspended sediment transport rates proposed by Schmied et al. (2006) has been improved by adding the bottom slope and scarping effects. The numerical model and the sediment transport formulas are briefly explained below before the proposed extensions are presented.

The numerical model is based on the time-averaged and depth-integrated continuity, cross-shore momentum, and energy equations (e.g., Kobayashi et al. 2005). The model predicts the cross-shore variations of the mean, $\eta$, and standard deviation of the free surface elevation, $\sigma_{\eta}$, and the mean and standard deviation ( $\bar{U}$ and $\sigma_{\eta}$ ) of the depth-averaged crossshore velocity as well as the time-averaged suspended sediment volume per unit of horizontal area, $V_{s}$. These variables can be predicted from outside the surf zone to the lower swash zone (mean water depth less than $1 \mathrm{~cm}$ ). The $V_{s}$ is computed using the formula for local sediment suspension due to wave energy dissipation proposed by Kobayashi and Johnson (2001) together with the probability of sediment suspension (Schmied et al. 2006). The cross-shore suspended sediment transport rate, $q_{s}$, is estimated as the product of the depthaveraged mean cross-shore velocity $\bar{U}$ and the suspended sediment volume: $q_{s}=a \bar{U} V_{s}$. The empirical suspended load parameter, $a$, includes implicitly the onshore sediment transport due to the correlation of the time-varying fluid velocity and concentration. The value of $a=1$ implies no correlation and all sediment in suspension is transported in the direction of $\bar{U}$, which is always offshore for the assumed impermeable beach with no overtopping. The value calibrated by Schmied $e t$ $a l$. (2006) was $a=0.2$. The bedload transport rate, $q_{b}$, is assumed proportional to the third power of the standard deviation of the cross-shore velocity, $q_{b}=b P_{b} \sigma_{U}^{3} /[g(s-1)]$, including the probability of sediment movement, $P_{b}$, where $g$ is the gravity acceleration and $s$ is the nondimensional specific gravity of the sediment. The empirical bedload parameter, $b$, was calibrated as $b=0.002$ by Schmied et al. (2006) using the

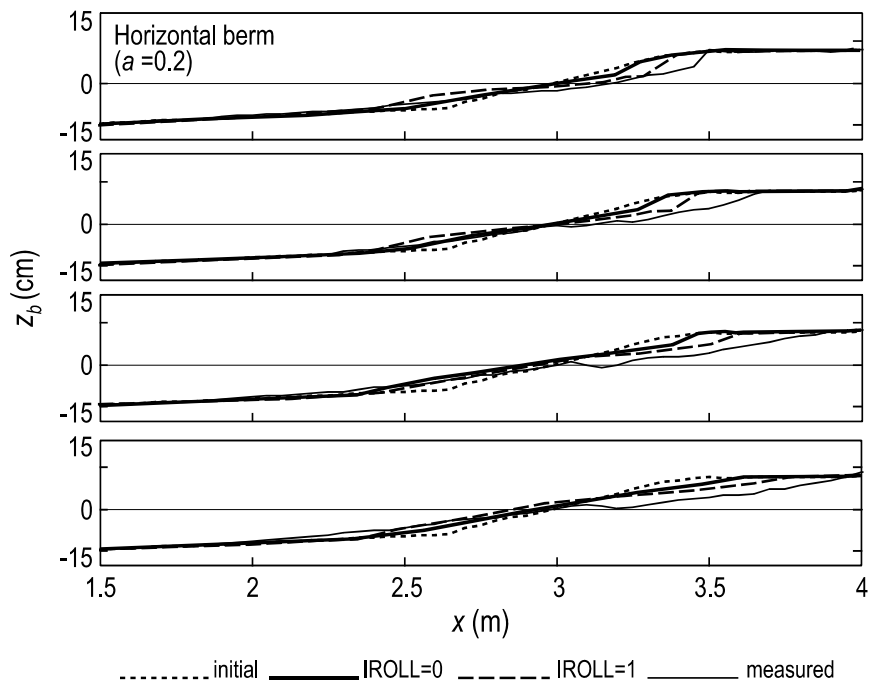

Figure 4. Profile evolution and model prediction for the horizontal berm test where suspended sediment parameter $a=0.2$ (default value); IROLL $=0$ and IROLL = 1 indicate computed results without and with roller effect, respectively. From top to bottom, steps I to IV.

Figura 4. Evolución del perfil y predicción para el ensayo de berma horizontal con el parámetro $a=0.2$ (valor por defecto). IROLL $=0$ e IROLL $=1$ indican resultados sin $\mathrm{y}$ con el efecto del roller incluido respectivamente. Del panel superior al inferior, pasos I al IV.

\section{Extensión para fondos de elevada pendiente y erosión por escarpe}

La formulación del transporte de fondo y en suspensión propuesta por Schmied et al. (2006) ha sido mejorada incluyendo los efectos de la pendiente del fondo y erosión por escarpe. En esta sección se presenta brevemente el modelo numérico y las fórmulas de transporte antes de describir las modificaciones propuestas.

El modelo numérico se basa en las ecuaciones, promediadas en el tiempo e integradas en la profundidad, de continuidad y conservación del momento transversal y la energía (e.g., Kobayashi et al. 2005). El modelo predice la variación transversal de la media, $\eta$, y la desviación estándar de la elevación de la superficie libre, $\sigma_{\eta}$, y la media y desviación estándar ( $\bar{U}$ y $\left.\sigma_{\eta}\right)$ de la velocidad del flujo transversal integrado en profundidad, así como el volumen de sedimentos en suspensión promediado en el tiempo por unidad de superficie horizontal, $V_{s}$. Estas variables pueden ser predichas desde fuera de la zona de rompiente hasta la zona baja de swash (profundidad media inferior a $1 \mathrm{~cm}$ ). El sedimento en suspensión, $V_{s}$, se calcula usando la fórmula de suspensión local de sedimento debida a la disipación de energía propuesta por Kobayashi y Johnson (2001) junto con la probabilidad de que el sedimento se encuentre en suspensión (Schmied et al. 2006). La tasa de transporte transversal de sedimento en suspensión, $q_{s}$, se estima como el producto de la velocidad transversal $\bar{U}$ y el volumen de sedimento en suspensión $V_{s}$, de la forma, $q_{s}=a \bar{U} V_{s}$. El parámetro empírico de transporte de carga en suspensión, $a$, 
water tunnel data of Ribberink and Al-Salem (1994) and Dohmen-Janssen et al. (2002), and the large-scale wave flume tests of Dohmen-Janssen and Hanes (2002).

\section{Bottom slope effect}

For alongshore uniform bathymetry, the bottom slope is limited to the cross-shore direction. The cross-shore bedload transport rate, $q_{b}$, is modified as

$$
q_{b}=\frac{b P_{b}}{g(s-1)} \sigma_{U}^{3} G_{s}
$$

where the bottom slope function $G_{s}$ is unity on a horizontal bottom and assumed to depend on the local bottom slope, $S_{b}=$ $\partial z_{b} / \partial x$, which is positive for an upward slope in the landward direction. The functional form of $G_{s}$ used by Bagnold (1966) for steady stream flow corresponds to $G_{s}=\tan \phi /\left(\tan \phi+S_{b}\right)$, where $\phi$ is the angle of internal friction of the sediment and $\tan \phi \cong 0.63$ for sand. Bailard and Inman (1981) modified this functional form for oscillatory flow on a gentle slope with $\left|S_{b}\right|<<\tan \phi$. This assumption is normally valid for a sand beach in the absence of berm or dune erosion. The slope effect on the cross-shore sand transport is secondary as long as $\left|S_{b}\right|<<\tan \phi$.

The bottom slope function $G_{s}$ is empirically expressed as:

$$
\begin{gathered}
G_{s}=\tan \phi /\left(\tan \phi+S_{b}\right) \text { for }-\tan \phi<S_{b}<0 \\
G_{S}=\left(\tan \phi-2 S_{b}\right) /\left(\tan \phi-S_{b}\right) \text { for } 0<S_{b}<\tan \phi
\end{gathered}
$$

where $G_{s}>1$ for $S_{b}<0$ and $G_{s}<1$ for $S_{b}>0$. The downward (upward) slope increases (decreases) the onshore bedload transport rate given by equation (1). Equations (2) and (3) yield $G_{s} \cong\left(1-S_{b} / \tan \phi\right)$ for $\left|S_{b}\right|<<\tan \phi$ and $G_{s}$ approaches a positive (negative) infinity as the slope $S_{b}$ approaches $-\tan \phi(\tan \phi)$. These asymptotic characteristics of $G_{s}$ appear physically realistic. For the following computation, use is made of $\left|G_{s}\right|<G_{m}=$ 10 so that the slope effect remains finite.

The effect of the bottom slope on suspended sediment transport was examined by Bailard and Inman (1981). The bottom slope effect on the suspended sediment transport rate is expected to be small because suspended sediment particles are not in contact with the bottom. The effect on the bottom slope may simply be included as the actual bottom area $\left(1+S_{b}{ }^{2}\right)^{0.5}$ exposed to the wave action per unit of horizontal area. The suspended sediment transport rate, $q_{s}$, given for an essentially horizontal bottom is modified as:

$$
q_{s}=a \bar{U} V_{s}\left(1+S_{b}^{2}\right)^{0.5}
$$

\section{Extension to steep swash zone}

The landward marching computation of the present timeaveraged model ends at the cross-shore location $x=x_{m}$ where tiene implícito el transporte hacia tierra debido a la correlación entre la velocidad del fluido, cambiante en el tiempo, y la concentración de sedimentos. El valor de $a=1$ implica ausencia de correlación y que todo el sedimento es transportado en la dirección de $\bar{U}$, siempre mar adentro para una playa supuestamente impermeable y sin rebosamiento. El valor calibrado por Schmied et al. (2006) fue $a=0.2$. La tasa de transporte de fondo, $q_{b}$, se supone proporcional a la tercera potencia de la desviación estándar de la velocidad transversal (equivalente a la velocidad orbital), $q_{b}=b P_{b} \sigma_{U}^{3} /[g(s-1)]$ incluyendo la probabilidad de inicio de movimiento del sedimento, $P_{b}$, donde $g$ es la aceleración de la gravedad y $s$ es la densidad específica adimensional del sedimento. El parámetro empírico de transporte de fondo, $b$, fue calibrado como $b=0.002$ por Schmied et al. (2006) empleando los datos en túnel de agua de Ribberink y Al-Salem (1994) y Dohmen-Janssen et al. (2002) y en canal de oleaje a gran escala de Dohmen-Janssen y Hanes (2002).

\section{Efecto de la pendiente del fondo}

Para el caso de batimetría uniforme longitudinalmente, los efectos de la pendiente del fondo se limitan a la dirección transversal. La tasa de transporte transversal de fondo $q_{b}$ es modificada como

$$
q_{b}=\frac{b P_{b}}{g(s-1)} \sigma_{U}^{3} G_{s}
$$

donde la función del efecto de la pendiente del fondo $G_{s}$ para un fondo horizontal es igual a la unidad y se supone dependiente de la pendiente local del fondo $S_{b}=\partial z_{b} / \partial x$, la cual es positiva para una pendiente ascendente en dirección a tierra. La función $G_{s}$ usada por Bagnold (1966) para un flujo de agua estacionario se corresponde con $G_{s}=\tan \phi /\left(\tan \phi+S_{b}\right)$ donde $\phi$ es el ángulo de fricción interna del sedimento y tan $\phi \cong 0.63$ para arenas. Bailard e Inman (1981) modificaron esta función para flujo oscilatorio sobre una pendiente suave con $\left|S_{b}\right|<<\tan$ $\phi$. Esta aproximación es normalmente valida para una playa de arena en ausencia de erosión de la berma o de la duna. El efecto de la pendiente del fondo es secundario siempre que $\left|S_{b}\right|$ $<<\tan \phi$.

La función del efecto de la pendiente del fondo $G_{s}$ se expresa empíricamente como

$$
\begin{gathered}
G_{s}=\tan \phi /\left(\tan \phi+S_{b}\right) \text { for }-\tan \phi<S_{b}<0 \\
G_{S}=\left(\tan \phi-2 S_{b}\right) /\left(\tan \phi-S_{b}\right) \text { para } 0<S_{b}<\tan \phi
\end{gathered}
$$

donde $G_{s}>1$ para $S_{b}<0$ y $G_{s}<1$ para $S_{b}>0$. La pendiente positiva (o negativa) aumenta (o disminuye) el transporte de fondo hacia tierra $q_{b}$ dado por la ecuación (1). Las ecuaciones (2) y (3) se reducen a $G_{s} \cong\left(1-S_{b} / \tan \phi\right)$ para $\left|S_{b}\right|<<\tan \phi$ y $G_{s}$ tiende hacia infinito (-infinito) cuando la pendiente tiende hacia $\tan \phi(\tan \phi)$. Este comportamiento asintótico de $G_{s}$ es físicamente plausible. Para los siguientes cálculos se emplea 
the mean water depth, $\bar{h}$, is less than $1 \mathrm{~cm}$. No reliable data exist for suspended sand and bedload transport rates in the zone that is wet and dry intermittently. Consequently, the following simple procedure is adopted to deal with the zone with the bottom slope $S_{b}>\tan \phi$. The cross-shore total sediment transport rate $q_{x}$ at $x=x_{m}$ is denoted by $q_{x m}$. If $q_{x m}$ is negative (offshore), $q_{x}$ is extrapolated linearly to estimate $q_{x}$ on the scarped face with $S_{b}>\tan \phi$.

$$
q_{x}=q_{x m}\left(x_{e}-x\right) /\left(x_{e}-x_{m}\right) \text { for } x_{m}<x<x_{e}
$$

where $x_{e}$ is the landward limit of the scarping zone with $S_{b}>$ $\tan \phi$. The extrapolated $q_{x}$ is in the range of $q_{x m} \leq q_{x} \leq 0$ and the scarping zone is eroded due to the offshore sediment transport. This simple procedure does not allow onshore sediment transport due to overwash.

\section{Comparison with the model}

The measured fall velocity, porosity (void fraction per unit volume of sand and water mixture), and specific gravity (ratio between the sand density $\rho_{s}$ and water density $\rho=1000 \mathrm{~kg} \mathrm{~m}^{-3}$ ) of the sand were $2.2 \mathrm{~cm} \mathrm{~s}^{-1}, 40 \%$, and 2.65, respectively. The angle of the sand internal friction is assumed to be $32^{\circ}$ (Bailard and Inman 1981). The computational procedure is the same as that used by Payo et al. (2006). Given the importance of undertow current (van Rijn et al. 2003), the profile evolution was computed with and without the roller effect where the roller increases the offshore undertow current (Kobayashi et al. 2005).

The computed and measured profiles are shown in figures 4 , 5, and 6. Berm erosion is predicted better for IROLL $=1$ because the roller increases the offshore return current and suspended sediment transport rate in shallow water as shown in figure 7. The computed cross-shore variations of the variables related to wave breaking, suspended load, and bedload plotted in figure 7 indicate that sand movement, suspension, and transport in these very small-scale tests occurred mostly on the berm itself. An increase in the empirical suspended load parameter, from $a=0.2$ to $a=0.4$, better predicts the berm erosion (fig. 6), suggesting a decrease in the correlation between the cross-shore velocity and the concentration, though some of the berm erosion was caused by the gradient of the longshore sand transport on the berm (alongshore variability noticeable in fig. 3b). The value of $a$ cannot be calibrated using the data affected by the alongshore variability.

\section{Performance of the model}

The predictability of the free surface and cross-shore velocity of the combined wave and current model has been shown to be as good as other profile models (e.g., Kobayashi et al. 2005). The predictability of the morphology was estimated using the Brier skill score (BSS) (e.g., van Rijn et al. 2003). This skill score compares the mean squared difference between the prediction and observation with the mean squared
$\left|G_{s}\right|<G_{m}=10$ de modo que el efecto de la pendiente del fondo permanece finito.

El efecto de la pendiente del fondo sobre el transporte en suspensión ha sido examinado por Bailard e Inman (1981). Es de esperar que este efecto sea poco significativo ya que las partículas en suspensión no están en contacto con el fondo. El efecto de la pendiente del fondo puede ser entonces modelado de forma sencilla incluyendo la superficie del fondo real $(1+$ $\left.S_{b}^{2}\right)^{0.5}$ expuesta a la acción del oleaje por unidad de área horizontal. La tasa de transporte de sedimento en suspensión $q_{s}$ dada para un fondo en esencia horizontal es modificada como

$$
q_{s}=a \bar{U} V_{s}\left(1+S_{b}^{2}\right)^{0.5}
$$

\section{Extensión a la zona de swash de elevada pendiente}

El límite hacia tierra del presente modelo esta determinado por la coordenada transversal $x=x_{m}$ donde la profundidad media del agua $\bar{h}$ es inferior a $1 \mathrm{~cm}$. Actualmente no existen datos simultáneos del transporte de fondo y en suspensión en la zona de swash. Por ello se adoptó el sencillo procedimiento para tratar la zona con pendiente del fondo $S_{b}>\tan \phi$ siguiente. La tasa de transporte total de sedimentos $q_{x}$ en $x=x_{m}$ se denota por $q_{x m}$. Si $q_{x m}$ es negativo (hacia el mar), $q_{x}$ se extrapola linealmente para estimar $q_{x}$ en el frente del escarpe con $S_{b}>\tan \phi$

$$
q_{x}=q_{x m}\left(x_{\mathrm{e}}-x\right) /\left(x_{e}-x_{m}\right) \text { para } x_{m}<x<x_{e}
$$

donde $x_{e}$ es el límite hacia tierra de la zona de escarpe donde $S_{b}$ $>\tan \phi$. El valor extrapolado de $q_{x}$ varía en el rango de $q_{x m} \leq q_{x}$ $\leq 0$ y el escarpe es erosionado debido al transporte hacia el mar. Este sencillo procedimiento no permite tranporte hacia tierra debido a rebosamiento.

\section{Comparación con el modelo}

Los valores medidos de la velocidad de caída, porosidad (fracción de huecos por unidad de volumen de mezcla de agua y sedimentos) y densidad específica (razón entre la densidad de la arena $\rho_{s}$ y la del agua $\rho=1000 \mathrm{~kg} \mathrm{~m}^{-3}$ ) del sedimento fueron de $2.2 \mathrm{~cm} \mathrm{~s}^{-1}, 40 \%$, y 2.65, respectivamente. El ángulo de fricción interna del sedimento se supone de $32^{\circ}$ (Bailard e Inman 1981). El procedimiento de cálculo es igual al usado por Payo et al. (2006). A la luz de la importancia del flujo de retorno (van Rijn et al. 2003), la evolución del perfil de playa fue calculada con y sin el efecto del roller incluido, el cual aumenta la corriente de retorno (Kobayashi et al. 2005).

Los perfiles medidos y estimados se muestran en las figuras 4, 5 y 6. La estimación de la erosión de la berma es mejor cuando se incluye el roller (IROLL $=1$ ) debido a que éste aumenta la velocidad de retorno y la tasa de transporte de sedimento en suspensión como se muestra en la figura 7. En esta misma figura, la variación transversal de los valores relacionados con la rompiente, el transporte en suspensión y de fondo, 


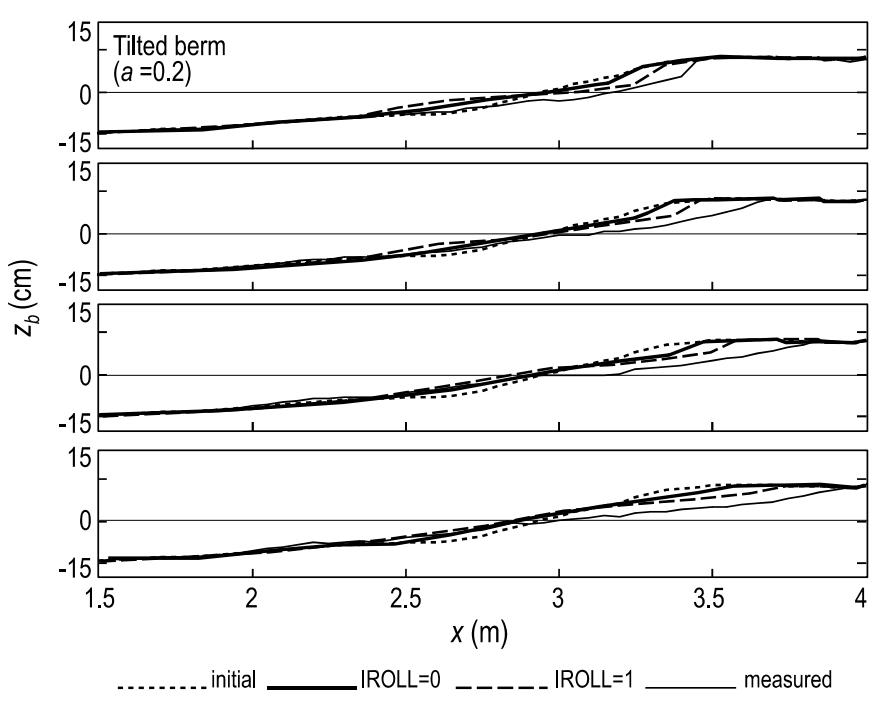

Figure 5. Profile evolution and model prediction for the tilted berm test where suspended sediment parameter $a=0.2 ; \mathrm{IROLL}=0$ and IROLL $=1$ indicate computed results without and with roller effect, respectively. From top to bottom, steps I to IV.

Figura 5. Evolución del perfil y predicción para el ensayo de berma inclinada con el parámetro $a=0.2$ (valor por defecto). IROLL = 0 e IROLL = 1 indican resultados sin y con el efecto del roller incluido respectivamente. Del panel superior al inferior, pasos I al IV.

difference of the measured change. Perfect agreement gives a $\mathrm{BSS}=1$, whereas modeling no change gives a $\mathrm{BSS}=0$. If the model prediction is farther away from the final measured condition than no change, the skill score is negative (BSS $<0$ ). The BSS is hence defined as:

$$
\text { BSS }=1-\left\lfloor\left(\left|z_{b, c}-z_{b, m}\right|-\Delta z_{b, m}\right)^{2} /\left(z_{b, 0}-z_{b, m}\right)^{2}\right\rfloor
$$

where $z_{b}$ is the bottom elevation, $z_{b, 0}$ is the initial profile, $\Delta z_{b, m}$ is the error of the measured elevation $(1 \mathrm{~cm}$ in this experiment), and indexes $m$ and $c$ stand for the measured and computed bottom elevations, respectively. It is noted that the absolute difference between the computed and measured values minus the measurement error cannot be smaller than zero and $\left(\left|z_{b, c}-z_{b, m}\right|-\Delta z_{b, m}\right)=0$ if this value is negative. This corresponds to the computed value within the measured error. A BSS of 1.0-0.8 is considered excellent, $0.8-0.6$, good; 0.6-0.3, fair; $0.3-0$, poor; and $<0$, bad. The cross-shore variation of the BSS for the horizontal and tilted berm tests, using calibrated values by Schmied et al. (2006), are shown in figures 8 and 9 .

The profile changes above the SWL are better predicted when the roller is included. The minimum predictability is located between the toe of the foreshore and below the SWL. The computed and observed changes just below the SWL were very small, as observed in nature (e.g., Muñoz-Pérez et al. 2001). The extreme sensitivity of the BSS when the denominator is small produced this low score. An additional local minimum of predictability occurred at the landward limit of the eroded berm, with a score of $0.6-0.4$ for the horizontal berm test and about 0.4 for the tilted berm test.

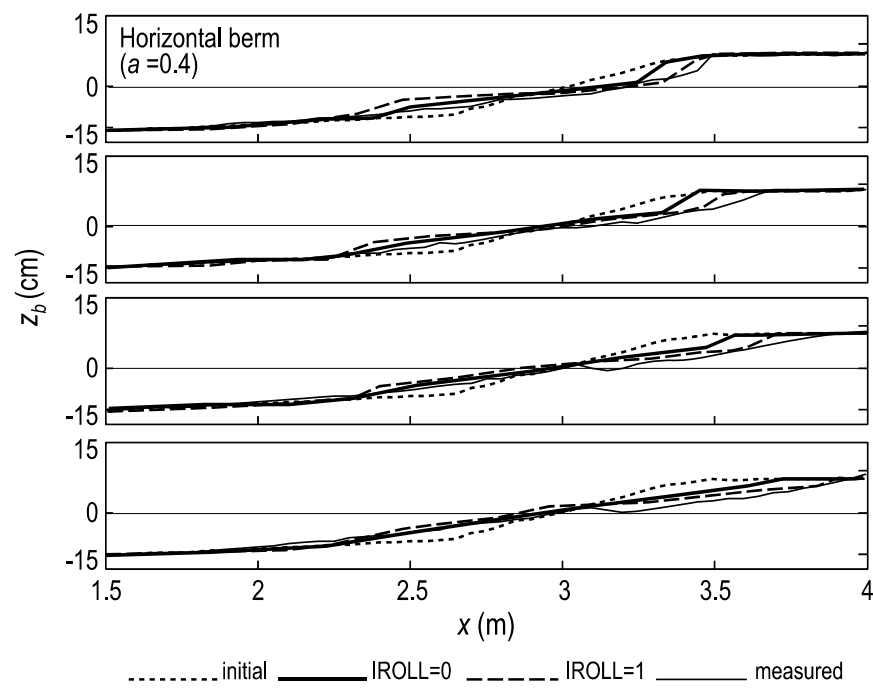

Figure 6. Profile evolution and model prediction for the horizontal berm test where suspended sediment parameter $a=0.4$ (doubled); IROLL $=0$ and $\mathrm{IROLL}=1$ indicate computed results without and with roller effect, respectively. From top to bottom, steps I to IV.

Figura 6. Evolución del perfil y predicción para el ensayo de berma horizontal con el parámetro $a=0.4$ (doble del valor por defecto). IROLL $=0$ e IROLL =1 indican resultados sin y con el efecto del roller incluido respectivamente. Del panel superior al inferior, pasos I al IV.

indican que el movimiento, suspensión y transporte en este ensayo a escala reducida tiene lugar en la misma berma. Si se aumenta el parámetro empírico de transporte en suspensión de $a=0.2$ a $a=0.4$, mejora la predicción de la erosión de la berma (fig. 6) sugiriendo una disminución de la correlación entre la velocidad transversal y la concentración de sedimentos. Sin embargo, parte de la erosión de la berma es debida al gradiente del transporte longitudinal (no uniformidad longitudinal apreciable en la fig. 3b). El valor de $a$ no puede ser calibrado empleando datos afectados por la variabilidad longitudinal.

\section{Capacidad predictiva del modelo}

La predictibilidad de la superficie libre y la velocidad transversal del modelo combinado de oleaje y corriente ha demostrado ser tan buena como la de otros modelos hidrodinámicos (e.g., Kobayashi et al. 2005). La predictivilidad de la morfología fue estimada usando la escala BSS (e.g., van Rijn et al. 2003). Esta escala de la capacidad predictiva del modelo compara la diferencia al cuadrado entre la predicción y la observación con la diferencia media al cuadrado del cambio observado. Una concordancia perfecta supone una puntuación de BSS = 1 mientras que una estimación de no cambio supone $\mathrm{BSS}=0$. Si la predicción del modelo es peor que el suponer no cambio, la puntuación es negativa $(B<0)$. Se define BSS como

$$
\text { BSS }=1-\left\lfloor\left(\left|z_{b, c}-z_{b, m}\right|-\Delta z_{b, m}\right)^{2} /\left(z_{b, 0}-z_{b, m}\right)^{2}\right\rfloor
$$

donde $z_{b}$ es la elevación del fondo, $z_{b, 0}$ es el perfil inicial, $\Delta z_{b, m}$ es el error cometido en la medida de la elevación $(1 \mathrm{~cm}$ en este 


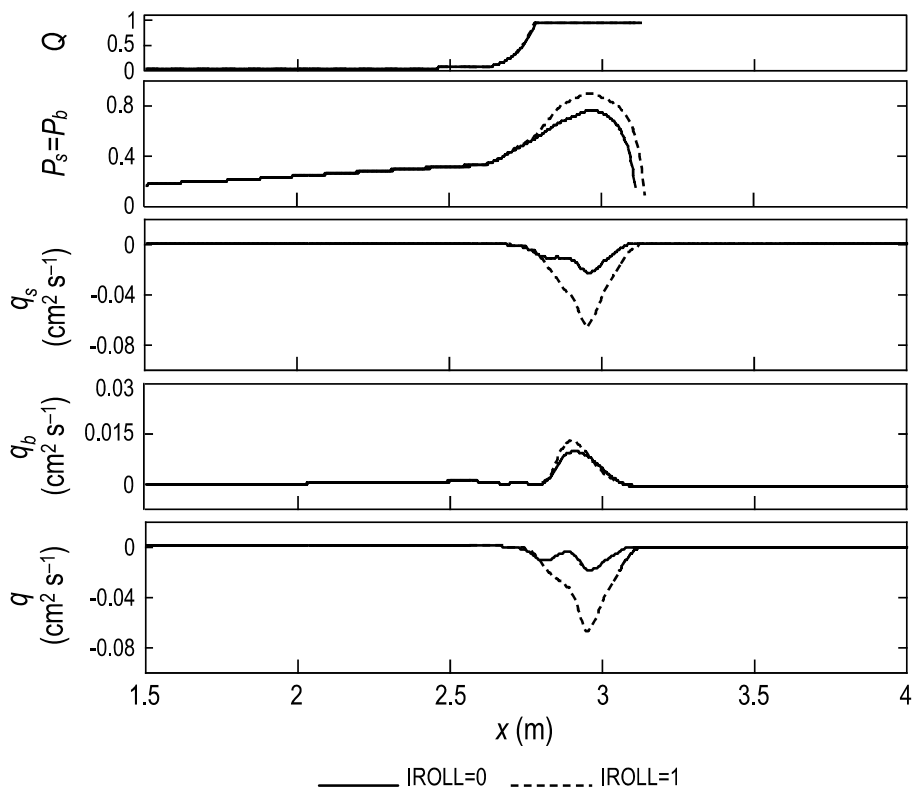

Figure 7. Computed cross-shore variations during step I of the horizontal berm test $(a=0.2)$. From top to the bottom: fraction of broken waves, $Q$; probability of sediment suspension, $P_{\mathrm{s}}$, which equals probability of sand movement, $P_{b}$; suspended sediment transport rate, $q_{s}$; bedload sediment transport rate, $q_{\mathrm{b}}$; and total transport rate, $q=\left(q_{\mathrm{s}}+q_{\mathrm{b}}\right)$.

Figura 7. Variación transversal estimada durante el paso I del ensayo de berma horizontal $(a=0.2)$. Por orden descendente, fracción de olas en rompiente, $Q$; probabilidad de encontrar el sedimento en suspensión, $P_{\mathrm{s}}$, que en este ensayo es igual a la probabilidad de inicio del movimiento, $P_{b}$; tasa de transporte de sedimentos en suspensión, $q_{s}$; tasa de transporte de sedimentos de fondo, $q_{b}$; tasa de transporte total, $q=\left(q_{s}+q_{b}\right)$.

\section{Conclusions}

An experiment in a muldirectional wave basin of scarping on sandy berms has been compared with the profile model of Schmied et al. (2006), including the additional effect of bottom slope on sediment transport. The water level was raised in four steps to successively reproduce the foreshore erosion, and the berm overwash, erosion and destruction. Horizontal and tilted berms were tested under normally incident irregular waves to compare the evolution of the profile without and with ponding. The initial beach was alongshore uniform but alongshore variability was observed in these tests probably due to the nonuniformity of the concrete slope in the wave basin. Predictability was estimated using the BSS. The sediment transport model gave a good predictability of the profile changes observed above the SWL for the horizontal berm test, and fair predictability for the tilted berm test. This decrease in predictability may have been caused by the ponding that appeared during the tilted berm test. When the empirical suspended load parameter, $a$, which has an uncertainty factor of two, is doubled, the performance of the model above the SWL becomes excellent, but this parameter cannot be calibrated using these tests with alongshore variability. The proposed profile model has been shown to reproduce berm erosion adequately when the bottom

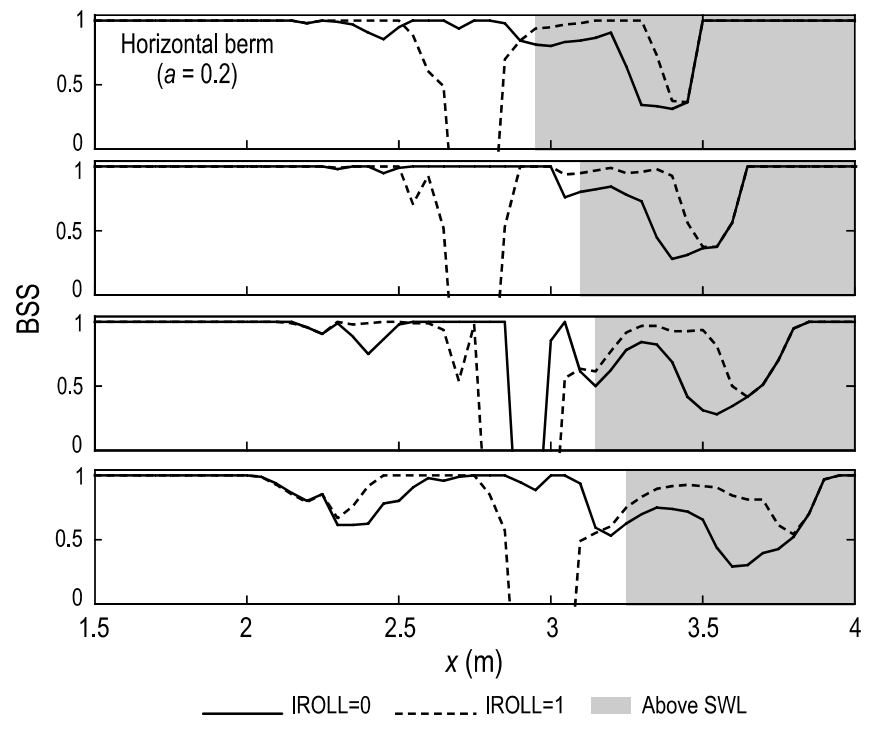

Figure 8. Cross-shore variation of the Brier skill score (BSS) for the horizontal berm test. From top to bottom, steps I to IV.

Figura 8. Variación transversal de los valores de la escala de Brier (BSS) para el ensayo de berma horizontal. Del panel superior al inferior, pasos I al IV.

experimento), y los subíndices $m$ y $c$ se refieren a los valores medidos y calculados, respectivamente. Nótese que el valor absoluto de la diferencia entre el valor calculado y el medido menos el error en la medida no puede resultar inferior a cero por lo que $\left(\left|z_{b, c}-z_{b, m}\right|-\Delta z_{b, m}\right)=0$ si este valor es negativo. Esto corresponde a un error en la predicción dentro del error en la medida. La predicción se considera excelente si $1.0 \geq \mathrm{BSS} \geq$ 0.8 , buena si $0.8 \geq$ BSS $\geq 0.6$, aceptable si $0.6 \geq$ BSS $\geq 0.3$, pobre si $0.3 \geq$ BSS $\geq 0$, y mala si BSS $<0$. En las figuras 8 y 9 se muestra la variación transversal del BSS para los ensayos de berma horizontal e inclinada empleando los valores calibrados por Schmied et al. (2006) de los parámetros empíricos.

Los cambios de perfil por encima del SWL son estimados mejor cuando se incluye el roller. La mínima predictibilidad se encuentra entre el pie del frente de playa y por debajo del SWL. Los cambios en el perfil estimados y observados por debajo del SWL son muy pequeños al igual que los observados en la naturaleza (e.g., Muñoz-Pérez et al. 2001). La extremada sensibilidad del BSS cuando el denominador es pequeño (cambio poco apreciable) produce esta baja puntuación. Otro mínimo local de predictibilidad aparece en el límite hacia tierra de la berma erosionada, con una puntuación entre 0.6 y 0.4 para el caso de la berma horizontal y de 0.4 para el caso de la berma inclinada.

\section{Conclusiones}

Se comparó la erosión experimental por escarpe de una berma arenosa en un tanque multidireccional de oleaje, con la predicha por el modelo de perfil propuesto por Schmied et al. (2006), el cual fue mejorado para incluir los efectos de la pendiente del fondo y la erosión del escarpe. El nivel de agua en el 


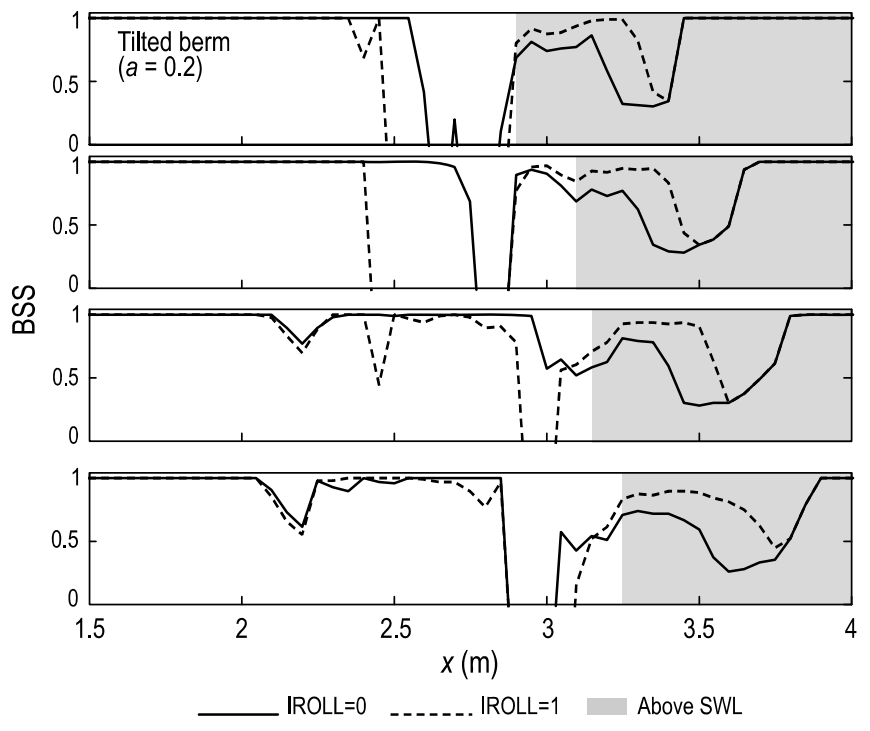

Figure 9. Cross-shore variation of the Brier skill score (BSS) for the tilted berm test. From top to bottom, steps I to IV.

Figura 9. Variación transversal de valores de la escala de Brier (BSS) para el ensayo de berma inclinada. Del panel superior al inferior, pasos I al IV.

slope effect is included. The sediment transport model needs further validation using field data before it can be used for engineering applications.

\section{Aknowledgements}

The first author was supported by the Spanish postdoctoral fellowship program MEC/Fulbright during his stay at the University of Delaware and the postdoctoral fellowship program of the Centennial Anniversary Foundation of Kumamoto University. The authors thank the two reviewers for their thorough reviews.

\section{References}

Bagnold RA. 1966. An approach to the sediment transport problem from general physics. US Geol. Surv., Prof. Paper, 422-I, 37 pp.

Bailard JA, Inman DL. 1981. An energetics bedload model for a plane sloping beach: Local transport. J. Geophys. Res. 86: 2035-2043.

Bouws E, Gunther H, Rosenthal W, Vincent C. 1985. Similarity of the wind wave spectrum in finite water depth. J. Geophys. Res. 90 (C1): 975-986.

Dohmen-Janssen CM, Hanes DH. 2002. Sheet flow dynamics under monochromatic nonbreaking waves. J. Geophys. Res. 107(C10): 3149, doi:10.1029/2001JC001045.

Dohmen-Janssen CM, Kroekenstoel DF, Hassan WN, Ribberink JS. 2002. Phase lags in oscillatory sheet flow: Experiments and bed load modeling. Coast. Eng. 47: 295-327.

Kobayashi N, Johnson BD. 2001. Sand suspension, storage, advection, and settling in surf and swash zones. J. Geophys. Res. 106(C5): 9363-9376.

Kobayashi N, Zhao H, Tega Y. 2005. Suspended sand transport in surf zones. J. Geophys. Res. 110, C12009, doi:10.1029/ 2004JC002853.

Muñoz-Pérez JJ, Tejedor L, Medina R. 2001. Las funciones empíricas ortogonales y los cambios en el perfil de playa a corto, medio y largo plazo. Física de la Tierra 13: 139-166. tanque fue elevado en cuatro pasos para reproducir la erosión del frente de playa y los sucesivos rebosamiento, erosión y destrucción de la berma. Se ensayaron perfiles con berma horizontal e inclinada sometidos a oleaje irregular de incidencia normal para comparar la evolución del perfil con y sin acumulación de agua tras la cresta de la berma. Se observó ausencia de uniformidad longitudinal probablemente debido a la ausencia de uniformidad en la pendiente de cemento sobre la que se construyo la playa inicialmente rectilínea. La capacidad predictiva del modelo de los cambios morfológicos por encima del SWL ha sido estimada empleando la escala de Brier. La precitibilidad fue buena para el caso de la berma horizontal y aceptable para el caso de la berma inclinada. Esta disminución en la predictibilidad puede deberse a la acumulación de agua tras la berma que sólo fue observada para la berma inclinada. Cuando el parámetro empírico de transporte en suspensión $a$, el cual tiene una incertidumbre asociada del orden de un factor 2, es duplicado, la calificación de la predicción es excelente; sin embargo este parámetro no puede ser calibrado empleando estos datos debido a la presencia de variabilidad longitudinal. El modelo de perfil propuesto ha mostrado reproducir adecuadamente la erosión de la berma cuando se incluye el efecto de la pendiente del fondo. El modelo de transporte de sedimentos necesita ser validado con datos de campo antes de poder ser usado en aplicaciones ingenieriles.

\section{Agradecimientos}

El primer autor ha sido beneficiario del programa de becas postdoctorales MEC/Fulbright del gobierno español durante su estancia en la Universidad de Delaware y el programa de becas postdoctorales del Centenario de la Fundación de la Universidad de Kumamoto. Los autores agradecen a los dos revisores por sus minuciosas revisiones.

Payo A, Kobayashi N, Kim K. 2006. Beach renourishment strategies. 30th Coastal Engineering Conference, World Scientific, Vol. 4, pp. 4129-4140.

Ribberink JS, Al-Salem AA. 1994. Sediment transport in oscillatory boundary layers in cases of rippled beds and sheet flow. J. Geophys. Res. 99: 12707-12727.

Schmied LD, Kobayashi N, Puleo JA, Payo A. 2006. Cross-shore sediment transport on beaches. 30th Coastal Engineering Conference, World Scientific, Vol. 3, pp. 2511-2523.

Seymour R, Guza RT, O’Reilly W, Elgar S. 2005. Rapid erosion of a small southern California beach fill. Coast. Eng. 52: 151-158.

Van Rijn LC, Walstra SJR, Grasmeijer B, Sutherland J, Pan S, Sierra JP. 2003. The predictability of cross-shore bed evolution of sandy beaches at the time scale of storms and seasons using processbased profile models. Coast. Eng. 47: 295-327.

Van Rijn LC, Walstra DJR, van Ormondt M. 2007. Unified view of sediment transport by currents and waves. IV. Application of morphodynamic model. J. Hydraul. Eng. 133(7): 777-793.

White TE. 1998. Status of measurement techniques for coastal sediment transport. Coast. Eng. 35: 17-45

Recibido en mayo de 2007; aceptado en noviembre de 2007. 